\title{
Evaluation of Physical-Chemical Indexes, Sugars, Pigments and Phenolic Compounds of Fruits from Three Apple Varieties at the End of Storage Period
}

\author{
Elena Andruţa MUREŞAN, Sevastiţa MUSTE*, Andrei BORŞA, Romina Alina VLAIC, Vlad MUREŞAN \\ Food Engineering Department, Faculty of Food Science and Technology, University of Agricultural Sciences and \\ Veterinary Medicine Cluj-Napoca, Calea Florești, 64. R0-400509, Cluj-Napoca, Romania \\ *sevastita.muste@usamvcluj.ro
}

Bulletin UASVM Food Science and Technology 71(1) / 2014

ISSN-L 2344-2344; Print ISSN 2344-2344; Electronic ISSN 2344-5300

\begin{abstract}
Apples are the most cultivated and consumed fruits in the world. They not only taste great, but there are also rich sources of monosaccharides, pigments, fibers, functional compounds such as polyphenols which are well-known for their antioxidant action. Due to the high level of apples consumption, it is important to monitor and know the detailed chemical composition of this fruits on the market shelf. The aim of this paper was to study the detailed chemical composition of apples from three varieties. Samples from three varieties (Ionathan, Golden Delicious and Starkrimson) were taken from the Romanian market. Individual sugars composition was performed by HPLC, total polyphenols content by Folin Ciocalteu method, antioxidant capacity by using the DPPH test, while pigments were analysed by spectrophotometric specific methods and the total starch content measured by a polarimetric method. Water content, acidity, total soluble solids and $\mathrm{pH}$ were also monitored through specific methods. There were found differences between varieties particularly in relation to the polyphenols content, carotenoids and chlorophyll. Regarding the individual sugars composition, fructose and glucose were predominant followed by sucrose for all samples. Values of starch, moisture, acidity, total soluble solids and the $\mathrm{pH}$ were according to other apple varieties found in literature. These results provide important information regarding the chemical composition of apple varieties from Romanian market, for both human direct consumption and industrial processing.
\end{abstract}

Keywords: Ionathan, Golden Delicious, Starkrimson, apple chemical composition, sugars, pigments, antioxidants.

\section{INTRODUCTION}

The importance of apples in the human diet is well known, global product quantities confirming that they are some of the most popular fruits. In 2011 apples ranked second worldwide, with a production of $2011 \sim 75$ million tons (FAO, 2013). In 2011 (the last year reported by the FAO, 2013), in the European Union, in terms of apple production , Romania ranked sixth, with a production of 620.000 tones, close to the Germany and Spain.

Apples are an important part of the human diet because they are a source of monosaccharides, minerals, dietary fiber and various biologically active compounds such as vitamin $\mathrm{C}$, and some phenolic compounds, which are known for their action as natural antioxidants (Miller and RiceEvans 1997).

Apples are eaten fresh or as compotes, jams, juices, juice concentrates, vinegars, flavorings, or extracts of various chemical compounds existing in the fruit. Apple fruit quality is very important, being determined by the content of sugars, organic acids and phenolic compounds. They have a very important role in taste characteristics such 
as flavor, bitterness, astringency and also color (Jihong et al., 2007).

Phenolic compounds concentration is strongly dependent on the apple variety and their maturity, closely related to the sensory and nutritional qualities of fruit. The starch content is an important factor for identifying appropriate maturation of the fruit.

Fruit color is a feature for assessing their quality and at the same time an indicator for assessing the maturity level at harvest (Muste, 2008). The color is a characteristic for species and is determined by the presence of pigments in cells of the epidermis and hypodermis. Interest in the beneficial effects of pigments on human health has stimulated an increase in demand for their use in food and supplementary food products.

Due to the high level of apples consumption as well as their health benefits, it is important to monitor and know the detailed chemical composition of this fruits on the market shelf. The aim of this paper was to study the detailed chemical composition of apples from three varieties from the Romanian market.

\section{MATERIALS AND METHODS}

\section{Samples characteristics}

Ionathan, Golden Delicious and Starkrimson apple varieties from Reghin region, harvested at technological maturity and stored in cells with a controlled atmosphere (temperature $0-2^{\circ} \mathrm{C}$, relative humidity $90-95 \%$, oxygen $1-3 \%$, carbon dioxide 1-2\%) for 115 days, were analyzed at consumption maturity.

\section{Moisture Determination}

The protocol used was based on AOAC Official Method. Moisture content was determined by drying in an oven at $103^{\circ} \mathrm{C} \pm 2{ }^{\circ} \mathrm{C}$ for 3 hours, the experiment being repeated until the weight was constant. The samples were cooled in a desiccator for one hour and weighed (AOAC, 1999).

\section{Soluble Solids Determination}

\section{- Refractometry}

The protocol used was based on the standardized ISO 2173:2003. Analyzed apple pulp was grounded with a Philips HR1614/00 650 W vertical blender and passed through a gauze. Samples were analyzed using a Carl Zeiss refractometer. The measured refractive index is related to the amount of soluble solids (expressed as the concentration of sucrose) using the conversion table or by direct reading on the scale of the refractometer (ISO 2173: 2003).

\section{Titratable Acidity Determination}

Determinations were made according to the international standard (ISO 750:1998), with some modifications.

\section{pH Determination}

This determination is based on the method proposed by Rosnah et al. (2012) with minor modifications. The $\mathrm{pH}$ was measured using a Hanna Instruments $\mathrm{pH}$ meter, prior calibrated to the $\mathrm{pH}$ 4.0 respectively $\mathrm{pH} 7.0$, using a buffer solution.

\section{Antioxidant Capacity Determination by DPPH Method}

The antioxidant capacity was determined by assessing the effect of elimination of free radicals (Free Radical Scavenging effect) over 1,1-diphenyl-2 -picrylhydrazyl (DPPH) radical. This determination is based on the method proposed by OdriozolaSerrano et al. (2008). An amount of $10 \mu \mathrm{l}$ of the methanolic extract from the analyzed samples, obtained according to the method described by Bunea et al. (2011), was mixed with $3.9 \mathrm{ml}$ of DPPH $(0.025 \mathrm{~g} / \mathrm{l})$ and $90 \mu \mathrm{l}$ of distilled water. The mixture was stirred and maintained properly in the dark for $30 \mathrm{~min}$. The absorbance of the samples was measured at $515 \mathrm{~nm}$ (Shimadzu $1700 \mathrm{UV}$-VIS) against a methanol blank. Results were expressed as percent over standard DPPH absorbance.

$$
R S A[\%]=\frac{A_{D P P H}-A_{P}}{A_{D P D H}} \times 100
$$

$$
\begin{aligned}
& \text { RSA [\%] - Radical Scavenging Activity; } \\
& \mathrm{A}_{\mathrm{DPPH}-} \text { DPPH absorbance; } \\
& \mathrm{A}_{\mathrm{P}}-\text { sample absorbance. }
\end{aligned}
$$

\section{Total Polyphenols Determination by Folin-Ciocalteu Method}

Total polyphenol content in whole apple was determined according to the method described by Cerbu etal. (2012). Absorbance was read at $750 \mathrm{~nm}$ with a Shimadzu UV-VIS 1700 spectrophotometer. The standard curve was carried out using concentrations of $0,0.25,0.50,0.75,1 \mathrm{mg} / \mathrm{ml}$ of gallic acid. Total polyphenol content in whole apple was expressed in gallic acid equivalents, mg of GAE/100 g FW (Sconta, 2012). 


\section{Carotenoid Pigments Determination}

Extraction was performed using the procedure described by Bunea et al. (2008) with some modifications. Carotenoids were extracted from the freeze-dried apple skins with liquid $\mathrm{N}_{2}$ (freeze drying) using as solvents: methanol, ethyl acetate, petroleum ether $(1: 1: 1, \mathrm{v} / \mathrm{v} / \mathrm{v})$. Successive extractions were performed. The extracts were combined, filtered and washed with distilled water, diethyl ether and a saturated solution of $\mathrm{NaOH}$. The ethereal phase was recovered and subjected to rotary evaporation at $35^{\circ} \mathrm{C}$. The remaining extract was dissolved in a known volume of methanol and stored at $-18{ }^{\circ} \mathrm{C}$ until it was subjected to analysis.

Estimation of carotenoids was determined using Shimadzu UV-VIS 1700 spectrophotometer by reading at $450 \mathrm{~nm}$ wavelength. Estimation of content of carotenoids was achieved by formula:

$X(m g$ of carotenoids $)=\frac{A \times V \times 10^{3}}{2500 \times l \times 100}$

$\mathrm{A}=$ absorbtion at $\lambda \max =450 \mathrm{~nm} ; \mathrm{V}=$ sample volume $(\mathrm{ml}) ; 2500=$ the molar absorption coefficient (E1\%); l = $1 \mathrm{~cm}$ - optical path length (Britton et al., 1995).

\section{Chlorophyll Pigments Determination}

Apple peel chlorophyll extraction was performed according to the method described by Lancaster et al. (1994) with some modifications. Absorbance was measured at 645 and $663 \mathrm{~nm}$. Chlorophyll content was calculated using Arnon (1949), equations:

$$
\begin{gathered}
\text { Chl a }\left(\mathrm{mg} \mathrm{g}^{-1}\right)=[(12.7 \times \mathrm{A} 663)-(2.6 \times \mathrm{A} 645)] \times \\
\text { ml acetone } / \mathrm{mg} \text { sample }
\end{gathered}
$$

Chl b $\left(\mathrm{mg} \mathrm{g}^{-1}\right)=[(22.9 \times \mathrm{A} 645)-(4.68 \times \mathrm{A} 663)] \times$ $\mathrm{ml}$ acetone / mg sample

$$
\text { Chl tot }=\mathrm{Chl} \mathrm{a}+\mathrm{Chl} \mathrm{b} \text {. }
$$

where: Chl a - clorophyll a; Chl b - clorophyll b; A663 - absorbance at $663 \mathrm{~nm}$; A645 - absorbance at $645 \mathrm{~nm}$; Chl tot - total clorophyll.

\section{Starch Determination by}

\section{Ewers Polarimetric Method}

The starch content of the apple pulp was determined using the Ewers polarimetric method
(ISO 10520: 1997) with some modifications. (Cerbu et al., 2011).

Starch content A $(\% \mathrm{w} / \mathrm{w})$ reported on dry weight was calculated using the formula:

$$
\boldsymbol{A}=\frac{2000}{\alpha_{D}^{20}} \times \frac{2.5 \alpha_{1}}{m_{1}} \times \frac{100}{w_{1}}
$$

where: : $\alpha_{1}$ - the numerical value of optical rotation in read polarimeter [polarimeter degrees]; $\alpha_{D}^{20} \alpha_{D}^{20}$ - specific numerical value for the measurement of optical rotation of pure starch [polarimeter degrees]; $\mathrm{m}_{1}$-sample weight $[\mathrm{g}]$; $\mathrm{w}_{1}$ - dry matter content of the determined sample $[\% \mathrm{w} / \mathrm{w}]$.

\section{Individual Sugars Determination by High Performance Liquid Chromatography (HPLC)}

Determination of individual sugars by high performance liquid chromatography to determine the concentration of sugar in apple juice samples obtained in the study were made in accordance with Honey Harmonised Methods of the International Commission (2002). The equipment used was a Shimadzu High Performance Liquid Chromatography (HPLC), consisting of controller, auto sampler, degasser, pump, IR detector, and the sugars separation was achieved on a modified Alltima Amnio 100A, $5 \mu \mathrm{m}, 250 \times 4.6 \mathrm{~mm}$ column. Mobile phase flow rate was $1.3 \mathrm{ml} / \mathrm{min}$. Column temperature was $30{ }^{\circ} \mathrm{C}$, injected sample volume being $20 \mu$ l. It was worked on isocratic conditions, using as mobile phase acetonitrile/water (75/25, $\mathrm{v} / \mathrm{v}$ ) mixture.

\section{RESULTS AND DISCUSSIONS}

The results on the chemical composition of the three apple varieties are presented in Table 1 and Table 2. Moisture values were between 82.09 and $85.4 \%$. These values are consistent with values reported by Campeanu et al. (2009).

Acidity is different depending on the variety, Ionathan variety register an acidity of $0.29 \%$ followed by Strakrimson variety with an acidity of $0.19 \%$ and Golden Delicious with an acidity of $0.17 \%$. These values were below the maximum limit of $0.31 \%$. Lower acidity leads to a better acceptance for apple to be consummated. In agreement with our results, Drogoudi et al. (2008) reported a higher content of total acidity in pulp 
Table 1. Physical-chemical indexes composition of the three apple varieties

\begin{tabular}{ccccc}
\hline Cariety & $\begin{array}{c}\text { Moisture } \\
\mathbf{( \% )}\end{array}$ & $\begin{array}{c}\text { Acidity } \\
\mathbf{( \% )}\end{array}$ & $\begin{array}{c}\text { Total soluble } \\
\text { ( } \mathbf{0} \text { Brix) }\end{array}$ & pH \\
\hline I & $85.34 \pm 0.17$ & $0.29 \pm 0.02$ & $23.25 \pm 0.35$ & $3.60 \pm 0.02$ \\
\hline GD & $85.43 \pm 0.16$ & $0.19 \pm 0.01$ & $19.25 \pm 0.35$ & $3.75 \pm 0.00$ \\
\hline S & $82.09 \pm 0.28$ & $0.17 \pm 0.02$ & $19.75 \pm 0.35$ & $4.12 \pm 0.01$ \\
\hline
\end{tabular}

I - Ionathan, GD - Golden Delicious, S - Starkrimson

Table 2. Chemical composition of the three apple varieties

\begin{tabular}{cccccc}
\hline & \multicolumn{2}{c}{ Chemical composition } \\
\hline Variety & $\begin{array}{c}\text { Polyphenols } \\
(\mathbf{m g} / \mathbf{m l} \text { galic } \\
\text { acid) }\end{array}$ & $\begin{array}{c}\text { Antioxidant } \\
\text { capacity } \\
\text { (\% DPPH } \\
\text { inhibited) }\end{array}$ & $\begin{array}{c}\text { Total } \\
\text { chlorophyll } \\
(\boldsymbol{\mu g} / \mathbf{g})\end{array}$ & $\begin{array}{c}\text { Total carotene } \\
(\boldsymbol{\mu g} / \mathbf{1 0 0} \mathbf{g})\end{array}$ & $\begin{array}{c}\text { Starch } \\
(\mathbf{m g} / \mathbf{g})\end{array}$ \\
\hline I & $23.09 \pm 0.59$ & $4.21 \pm 0.07$ & $82.58 \pm 0.00$ & $702.48 \pm 0.00$ & $3.71 \pm 0.31$ \\
\hline GD & $15.56 \pm 0.12$ & $4.13 \pm 0.00$ & $86.40 \pm 19.00$ & $275.13 \pm 0.00$ & $4.85 \pm 0.27$ \\
\hline S & $65.74 \pm 0.58$ & $4.91 \pm 0.07$ & $15.30 \pm 2.00$ & $670.64 \pm 0.00$ & $4.88 \pm 0.27$ \\
\hline
\end{tabular}

I - Ionathan, GD - Golden Delicious, S - Starkrimson

for "Granny Smith" apple variety, compared to the other varieties evaluated.

The content of total soluble differs depending on the variety of apple. Were recorded values between 19.25 and $23.25^{\circ}$ Brix. These values are consistent with values reported by Sestras et al. (2009).

Fruit $\mathrm{pH}$ varies depending on the variety, Ionathan variety registered lowest value in comparison with the other studied varieties. Our results are in agreement with those reported by Henriquez et al. (2010) who obtained similar values of $\mathrm{pH}$.

In apples as well as in other fruits, the content of total phenolic compounds (TPC) varies depending on variety, harvest time and storage conditions. TPC large variation also occurs according to the apples color red, yellow, green, or bicolour skin but also because of the apples pulp which can be more or less bright and colorful (Drogoudi et al., 2008). This can be seen in the case of our experiment, so Starkrimson variety had the highest content in TPC, followed by Golden Delicious variety and Ionathan (Tab. 2). Regarding antioxidant capacity there were no major differences between these varieties, having an average antioxidant capacity.

Chlorophyll content varies from one variety to another, as Golden Delicious had recorded the highest total chlorophyll content followed by Ionathan variety. Starkrimson variety recorded a slightly lower content (Tab. 2). Chlorophyll content varies depending on the variety and on the light intensity and exposure of fruit in the tree crown.

Carotenoid content was also different for each variety. Golden Delicious recorded the lowest levels of carotenoids, $275.13 \mu \mathrm{g} / 100 \mathrm{~g}$. This was observed by Lizabethlister (1994) when for the Golden Delicious variety were recorded lower values compared to the other varieties studied. Changes in the levels of carotenoids are due to high intensity of light, temperature fluctuations and variety. These factors are well known for their 

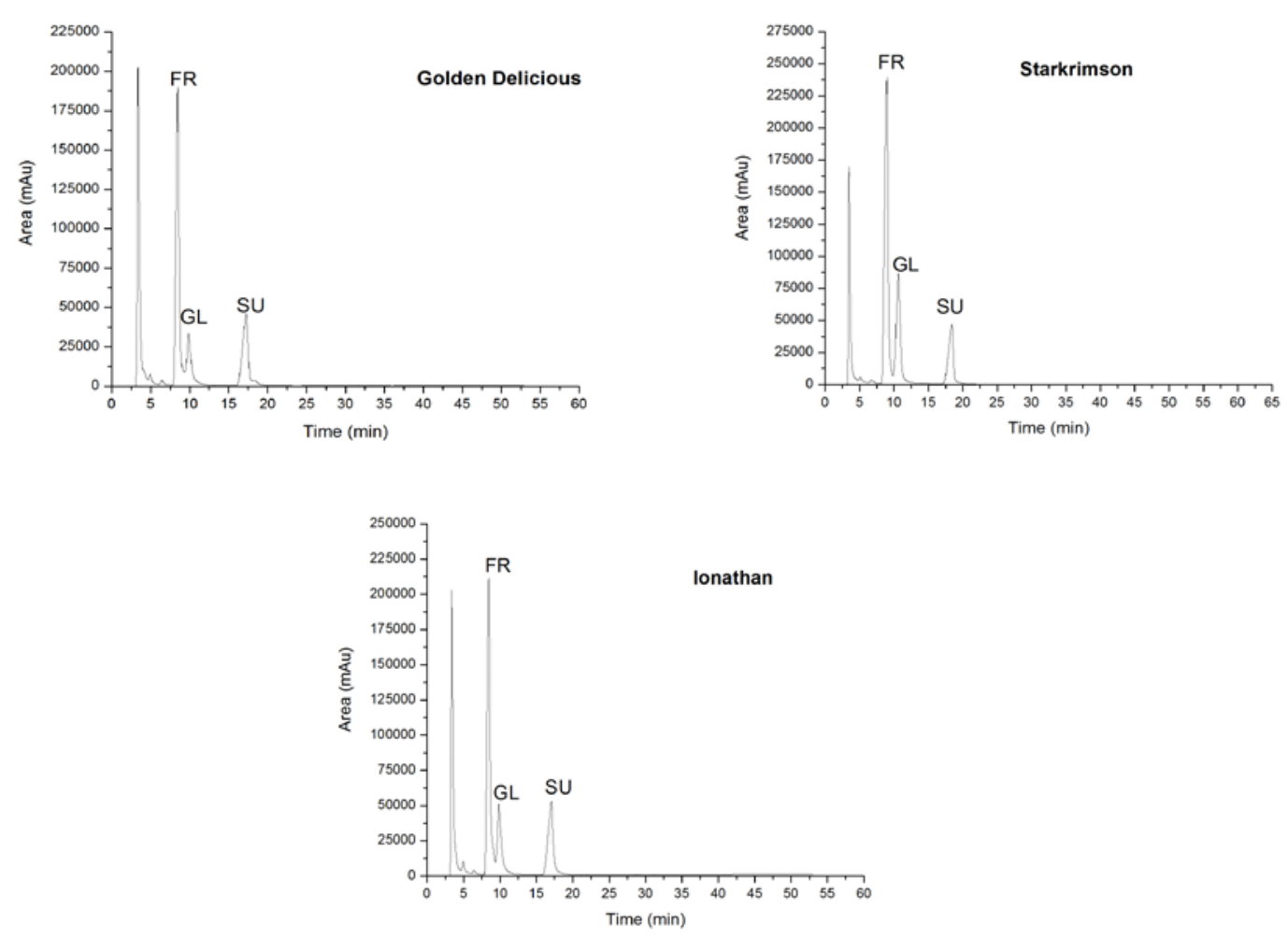

Fig. 1. Quantification of fructose (FR), glucose (GL) and sucrose (SU) from apples fruits (Ionathan, Golden Delicious and Starkrimson) by HPLC

influence on the degradation of pigments (Britton et al., 1995).

The starch content is quite low for all three studied varieties because it has been converted into monosaccharides. Thus Ionathan variety recorded a value of $3.71 \mathrm{mg} / \mathrm{g}$, the Starkrimson variety recorded $4.88 \mathrm{mg} / \mathrm{g}$ and Golden Delicious variety recorded $4.85 \mathrm{mg} / \mathrm{g}$.

Regarding the content of sugars, fructose, glucose and sucrose were identified as the major monosaccharide found in fruits apple (Fig. 1).

Fructose level was always higher than glucose and sucrose (Fig. 1). This was observed by Jihong et al. (2007) for Delicious, Orin, Fuji and Ralls varieties. Fructose content varies depending on the variety, Starkrimson variety registered a content of $12.92 \mathrm{~g} / 100 \mathrm{~g}$ juice, Ionathan variety recorded a $9.91 \mathrm{~g} / 100 \mathrm{~g}$ juice and Golden Delicious variety recorded a content of $8.62 \mathrm{~g} / 100 \mathrm{~g}$ juice.

The content of glucose also varies for all three apple varieties, Starkrimson variety recorded a content of $4.01 \mathrm{~g} / 100 \mathrm{~g}$ juice, Ionathan variety registered a content of $2.00 \mathrm{~g} / 100 \mathrm{~g}$ and Golden
Delicious registered a content of $1.49 \mathrm{~g} / 100 \mathrm{~g}$ juice.

In terms of sucrose content, Ionathan variety gained $4.29 \mathrm{~g} / 100 \mathrm{~g}$ juice followed by Starkrimson variety (containing $3.77 \mathrm{~g} / 100 \mathrm{~g}$ juice) and Golden Delicious variety with a content of $3.49 \mathrm{~g} / 100 \mathrm{~g}$ juice. The levels of glucose, fructose and sucrose of the studied samples from this paper is in agreement with the ranges reported by Jihong et al. (2007).

\section{CONCLUSION}

Sugars profile of apple is an important component of the chemical composition for fruit quality assessment and provides valuable information about the authentication of apple juice.

Content in phenolic compounds is also one of the most important factors for the evaluation and characterization of apple varieties regarding their nutritional value and potential use for different products.

Following the results obtained, all three apple varieties are suitable for both fresh consumption and as compotes, juices or jams. 


\section{REFERENCES}

1. Arnon, D.I. (1949). Copper enzymes in isolated chloroplasts. Polyphenol oxidase in Beta vulgaris. PlantPhysiol, 24:1-15.

2. Bunea, A. et al. (2011). Comparative polyphenolic content and antioxidant activities of some wild and cultivated blueberries from Romania. Not Bot Horti Agrobo, 39:7076.

3. Bunea, A. et al. (2008). Total and individual carotenoids and phenolic acids content in fresh, refrigerated and processed spinach (Spinacia oleracea L.). Food Chemistry, 649-656.

4. Britton, G. et al. (1995). Carotenoids. Birkhauser Verlag: Basel, Swtzerland, Vol.1A, 1B.

5. Cerbu, E.A. et al. (2012). Total phenolic content changes during apple growth as a function of variety and fruit position in the crown. Journal of Agroalimentary Processes and Technologies, 18: 341-344.

6. Cerbu, E.A. et al. (2011). Relationship between the Polarimetric Determination of Starch and the Starch Iodine Index in Apple Variety Jonathan, Bulletin UASVM Agriculture, 68:533.

7. Campeanu, G. et al. (2009). Chemical composition of the fruits of several apple cultivars growth as biological crop. Not. Bot. Hort. Agrobot. Cluj 37:161- 164.

8. Drogoudi, P. Z. et al. (2008). Peel and flesh antioxidant content and harvest quality characteristics of seven apple cultivars. Scientia Horticulturae 115:149-1.

9. Henriquez, C. et al. (2010). Determination of antioxidant capacity, total phenolic content and mineral composition of different fruit tissue of five apple cultivars grown in chile. Chilean Journal of Agricultural Research 70:523536.

10. Zheng, H. (2012). A profile of physicochemical and antioxidant changes during fruit growth for the utilisation of unripe apples. Food Chemistry, 131:106-110.

11. Lancaster, J. et al. (1994). Skin Color in Apples-Influence of Copigmentation and Plastid Pigments on Shadeand Darkness of Red Color in Five Genotypes. J. Amer. Soc. Hort. Sci. 119:63-69.

12. Lizabethlister, C. (1994). Biochemistry of fruitcolour in apples (Malus pumilaMill.). University of Canterbury, Christchurch, New Zealand.
13. 13. Miller, N. J. and Rice-Evans, C. A. (1997). The relative contributions of ascorbic acid and phenolic antioxidants to the total antioxidant activity of orange and apple fruit juices and blackcurrant drink. Food Chemistry, 60:331337.

14. Muste, S. (2008). Materii prime vegetale în industria alimentară. Editura AcademicPres, Cluj-Napoca.

15. Odriozola-Serrano, I. et al. (2008). Effect of minimal processing on bioactive compoundsand color attributes of fresh-cuttomatoes. Science Direct, LWT, 41:217-226.

16. Rosnah, S. et al. (2012). Chemical composition changes of two water apple (Syzygium samaragense). International Food Research Journal 19:167-174.

17. Sconța, Z. M. (2012). Extraction, Purification, Characterization and in vitro testing of anthocyaninrich fractions obtained from aronia melanocarpa and vaccinium Sp., PhD Thesis, Cluj-Napoca, România.

18. Sestras, A. et al. (2009). The influence of fruit position in the crown of trees on the sugar content and morphological traits of apple fruits, Bulletin UASVM Horticulture, 66.

19. Jihong, W. et al. (2007). Chemical compositional characterization of some apple cultivars. Food Chemistry 103:8893.

20. *** FAO (2013). FAOSTAT - FOOD AND AGRICULTURE ORGANIZATION OF THE UNITED NATIONS. http://faostat.fao.org/site/567/DesktopDefault. aspx?PageID=567\#ancor (23.11.2013)

21. *** HARMONISEDMETHODS OF THE INTERNATIONAL HONEYCOMMISSION (2002). IHC responsible for the methods: Stefan Bogdanov Swiss Bee Research Centre FAM, Liebefeld, CH-3003 Bern, Switzerland.

22. *** AOAC (1999). Official methods of analysis. 16th ed. 5th revision. Volume II. Chapter 44. Subchapter 4. Cunnif, P. (ed.) AOAC International, Washington, D.C., USA.

23. *** ISO (1997). International Standard, ISO 10520, Native starch - Determination of starch content - Ewers polarimetric method.

24. *** ISO (1998). Uganda Standard, US ISO 750, Fruit and vegetable products - Determination of titratable acidity.

25. *** ISO (2003). International Standard, ISO 2173, Fruit and vegetable products Determination of soluble solids Refractometric method. 